\title{
ETHICAL CONSUMPTION FOR THE PROMOTION OF HUMAN DIGNITY IN A GLOBALIZED WORLD
}

\author{
CONSUMO ÉTICO PARA A PROMOÇÃO DA DIGNIDADE HUMANA NUM MUNDO \\ GLOBALIZADO
}

\begin{abstract}
Mateus Bertoncini
Pós-Doutor em Direito pela UFSC. Doutor e Mestre em Direito do Estado pela UFPR. Professor do Corpo Docente Permanente do Programa de Mestrado em Direito Empresarial e Cidadania do Centro Universitário Curitiba (UNICURITIBA). Professor Titular de Direito Administrativo da Faculdade de Direito de Curitiba. Professor de Direito Administrativo da Fundação Escola do Ministério Público do Estado do Paraná (FEMPAR). Procurador de Justiça do Ministério Público do Estado do Paraná. E-mail: mateusbertoncini@uol.com.br
\end{abstract}

Elaine Braga Martins Ribeiro Lins Mestranda em Direito Empresarial e Cidadania do Unicuritiba. Especialista em Direito e Processo do Trabalho pela FCSF. Graduada em Direito pela UFSC. Analista Judiciária da JF/PR. E-mail: elaine_bmr@hotmail.com

Recebido em: 28/12/2017 Aprovado em: 28/02/2019

\begin{abstract}
This article is a study on consumer ethics. Its purpose is to foster consumption practices that contribute to the reduction of violations of the human dignity, as well as to contribute to the maintenance of an ecologically balanced environment. It starts with a study on general notions of ethics. Then, it moves on to an approach on the human dignity. Aspects related to the consumer society and environmental sustainability are elicited. It presents as a key problem the issue of the modern society's overconsumption, in a global perspective, fed by economic and selfish interests that generate serious environmental and social consequences, which need to be researched, understood and equated not only scientifically but also in the perspective of ethics, in the construction of the so-called ethical consumption, in a way that promotes the sustainability of the planet and the human dignity, as a necessary response to said anti-ethical or unethical consumption, which is absolutely unsustainable. Finally, topics related to impacts on Economy and social responsibility are addressed. Deductive and critical method were employed, grounded in bibliographical research.
\end{abstract}

Keywords:Ethical Consumption. Human Dignity. Sustainability.

RESUMO: Este artigo é um estudo sobre o consumo ético. O objetivo é debater práticas de consumo que contribuam para a manutenção de um ambiente ecologicamente equilibrado e para redução das violações da dignidade humana. Começa-se com um estudo sobre noções gerais de 
ética. Então, passa-se à uma abordagem sobre a dignidade humana. São trabalhados os aspectos relacionados à sociedade de consumo e à sustentabilidade ambiental. Apresenta-se como problemachave a questão do excesso de consumo da sociedade moderna, numa perspectiva global, alimentada por interesses econômicos e egoístas que geram graves consequências ambientais e sociais, temas que precisam ser pesquisados e entendidos não só cientificamente, mas também na perspectiva ética, na construção do chamado consumo ético, de forma a promover a sustentabilidade do planeta e a dignidade humana, como uma resposta necessária ao referido consumo antiético ou aético, o que é absolutamente insustentável. Finalmente, abordam-se os tópicos relacionados aos impactos sobre Economia e responsabilidade social. Foi empregado na pesquisa o método dedutivo e crítico, fundamentado em pesquisa bibliográfica.

Palavras-chave: Consumo Ético. Dignidade Humana. Sustentabilidade.

\section{INTRODUCTION}

The present discussion deals with issues related to consumer ethics as a tool for the promotion of human dignity in a globalized world in which market and individual economic interests prevail.

In the last decades, society has evolved towards greater protection of the human dignity. In this sense, there is an interest in studying mechanisms available for the civil society to defend a more ethical consumption behavior.

Pondering on the desirable ethical behavior in consumer relations, it is sought to identify behaviors and actions of the government and of the civil society that may contribute to the reduction of the disrespect to the human dignity due to the externalities generated by excessive consumption.

Research is justified in the interest of preserving an ecologically balanced environment, of good faith in consume relations and of protecting vulnerable people, be them consumers or not.

From this perspective: how can ethical consumption contribute to promote human dignity in a globalized world? To what extent can ethical consumption negatively affect the economy?

Deductive and critical method were employed, grounded in bibliographical research. The research made use of secondary data sources available on the internet.

\section{NOTIONS ON ETHICS}

The human being, throughout its existence, is many times in doubt of what would be the correct way to act. All sorts of dilemmas arise, such as, i.e., should I always tell the truth or is sometimes lying the most sensible thing to do? These intimate questions that we ask ourselves in the face of a problem lead us to resort to norms, value judgments, all kinds of arguments or reasons to justify the choice we make and we thus have a practical-moral behavior (SANCHEZ VÁSQUEZ, 2013, pp. 16-17).

Subsequently, as humanity evolved, we proceeded to the phase of reflection on practicalmoral behavior, and then the reflex morals emerged .This passing from effective morals to reflex morals coincides with the start of philosophical thought and the resolution of ethical issues, which are characterized by their generality (SANCHEZ VÁSQUEZ, 2013, p. 17). According to Sánchez Vásquez (2013, p. 17), "defining what is good is not a moral problem whose solution rests with the individual in each particular case, but a general problem of a theoretical nature, of competence of the moral investigator, that is, ethics."

What characterizes an ethical problem and distinguish it from a moral problem is its generality, as being "the best behavior from the moral point of view". "This way, the selfish aspects 
of conduct are left aside, focusing on the general perspective, which is the good, in a universe of different behaviors" (SANCHEZ VÁSQUEZ, 2013, p. 18).

Along with the best behavioral choice (the desirable one) comes responsibility, which, in turn, is linked to freedom. Consequently, for the citizen to act responsibly in its choices, it should be free to decide and act in an objective situation.

According to Sánchez Vásquez (2013, p. 23), "Ethics is the theory or science of mankind's moral behavior in society. That is, it is a science of a specific form of human behavior".

Furthermore, states Sánchez Vásquez (2013, p. 24), "Its research subject consists of several types of human acts: the conscious and voluntary acts of individuals that affect other individuals, certain social groups or society as a whole".

This is why consumer ethics seeks to establish morally desirable behaviors of social agents in consume relations.

\section{THE HUMAN DIGNITY}

Brazil, inspired by international law, introduced in its legal system, through the 1988 Constitution, the fruit of the constitutionalisation of human rights, a special attention to major (immaterial) assets, which above all characterize the personality, the so-called human rights, registered therein as guarantors of the humandignity.

It starts with article 1, item III, of the Constitution, which provides for the "human dignity" as one of the foundations of the Federative Republic of Brazil. That is, the spirit of our Constitution is to safeguard the citizen's "dignity", safeguarding it from any threat or harm.

We can also mention article 3, which places as one of the key objectives of the Brazilian Republic the construction of a free, fair and solidary society. This is where everybody's responsibility for solidarity and social justice arises from. Therefore, it is incumbent on everybody, even as consumers, to help prevent any acts that threaten the dignity of the human person from continuing to happen. One highlights, in this sense, the provisions of article 225 of the Federal Constitution 1988, according to which it is the duty of the Public Authorities and of society to protect the environment for both the present and future generations (intergenerational responsibility).

Therefore, it is essential that more attention is paid to excessive and unbridled consumption that results in the constitution of a liquid society (BAUMAN, 2013) or of the discard, whose goods rapidly cease to be objects of desire and are discarded and replaced by newer ones. This liquidity of society ends up affecting the human being who, when he no longer adapts to the rapid changes of the consumer society, when he is no longer recyclable, becomes disposable as well. (BAUMAN, 2005). Besides the effect on human dignity, there is the environmental issue.

The environmental problem originated with the Industrial Revolution and sprang up in modernity by shaping the society of consumption. The environmentally balanced environment is a fundamental right, its harm entails a violation of the human dignity, pursued by Constitution (article 1, III c/c, article 225, all of CF/88).

In consume relations, on many occasions, we find ourselves in situations of choices between one product or another, between one brand or the other. That should guide us in a decision which cannot be simply: what is best for me, selfishly speaking; but what, besides being good for the consumer, is also good for humanity. And, for 'good for humanity', must bed understood as the choice for ethical companies, which respects human rights, the human dignity or the environment.

The theoretical basis of consumer ethics relates to the care on human rights. According to Prado (apud BITTAR, 2013, p. 138), "it is a question of thinking about the improvement of 
democracy and of the culture of human rights, based on the development of social practices capable of carrying an ethics of care."

The act of consumption can, in certain situations, negatively affect the life of other individuals, and in these cases the unethical consumption would be characterized. Irresponsible consumption can also cause the degradation of the environment and scarcity of natural resources. The role of consumer ethics is to avoid these consumption habits that imply disrespect in regard to others, hence ensuring the protection of human dignity of those who are most frequently hidden in the consumption relation.

It is important to remember Kant $(2003,293)$, in his work The Metaphysics of Morals, when he discusses the duty of love in particular, in the chapter addressing the doctrine of the elements of ethics :

\begin{abstract}
One who finds satisfaction in the well-being (salus) of human beings simply as human beings, for whom one is well when things go well for all others, is called a friend of humanity in general (a philanthropist). (...) One who is indifferent to how things are for others, as long as they well themselves, is selfish (solipsistic).
\end{abstract}

Kant's lesson is of enormous value in the sense of caring for others and not just for our selfish interests. Basically, the indifference to the problems of others sooner or later is reflected on me as well, whether through social violence or through the scarcity of natural resources. The mere fact that a company disrespects labourers rights, subjecting the worker to debt bondage, for example, reverberates throughout the whole society, as a cry of injustice. We have to listen to this cry and make the right decision, ceasing to consume products from companies that harm human beings in their dignity, the practical application of the duty of love to others, as advocated by Kant.

\title{
3 THE CONSUMPTION SOCIETY
}

With the Industrial Revolution, there was a race for production, which culminated in the huge supply of new products to the market and, in the modern times, with the technological advance and, consequently, of the production, and society is experiencing a stage of 'consumption for consumption'. Consuming is cool because it gives "status." It is the "reification" of man, as announced by Bauman (2011, p. 65): "We are all under pressure to consume more, and in this path, we ourselves become products in the consumer and labor markets.".

One of the reasons why so many things are currently being produced at such a fast rate is the technological development and transformation from a Fordist society to a technological one, with greater ease of production on large scale, and much more rapidly than in the past. We arrive at a new society where exaggerated consumption is encouraged and the turnover of the products put on the market is advancing, mainly due to the variety of products put on the market and the intense advertising efforts of multinationals (marketing).

A society full of futility and disposability is shaped. A survey conducted by the company Marketing Analysis ${ }^{1}$, in partnership with the Consumer Defense Institute (IDEC), found that most Brazilians prefer to buy a new electronic product instead of repairing the old one. This behavior can be justified by the high cost of repairing the damaged product, which makes it uninteresting for the consumer. On the other hand, this behavior can be motivated by the relentless search for novelties in the market. It is the satisfaction of the ego with the happiness found in the acquisition

\footnotetext{
${ }^{1}$ The study shows how consumers are bringing forward the exchange of products to possess modern equipment and more advanced technology. Psychological and social factors intensify behaviors in which people stop consuming by necessity and begin to consume by habit. (MARKETINGANALYSIS, 2014).
} 
of a new product. According to Bauman (2008: 22), this race for whatever is new occurs in the desire to stand out from the crowd:

\begin{abstract}
In addition to dreaming with fame, another dream, that of no longer being dissolved and remaining dissolved in the gray, faceless and insipid crowd of commodities, of becoming a remarkable commodity, noted and coveted, a commented commodity, which stands out from the crowd, and is impossible to ignore, ridicule or reject. In a consumer society, becoming a desirable and desired commodity is the stuff that dreams and fairy tales are made of. (emphasis added).
\end{abstract}

Bauman foresees the constant search for the popularity of the citizen, that goes from being a consumer to being an object of consumption, in that it "gets out of" the "monotonous and gray crowd" of the goods and ascends to the stardom. We are, therefore, also goods, with the rampant consumption, in order to be able to stand out from the crowd through the objects one has. This is the most serious consequence of "living for consumption", and that, in a certain way, consists in the total absence of ethics in consumption.

In today's society, based on the selfish perspective of life and the frantic pursuit of happiness, there seems to be no room for solidarity and fraternity, as the case, i.e., of the chocolate industry, where some multinationals obtain the chocolate we consume with the use of child slave labour in one of the stages of the production chain (BERTONCINI; LINS, 2016, p.209). Although we are aware of this fact, do we make the ethically correct choice when purchasing the product? Another equally relevant case would be the adoption of environmentally friendly carrier bags to use when shopping in supermarkets. Do people actually stop using plastic bags to contribute to an ecologically balanced environment? And, with respect to companies that repeatedly disregard the labour rights of employees, do we stop buying from them? In fact, most of the time, our choices are made for the price and the pleasure that objects provide us with and we do not worry about ethical issues.

Globalization, while beneficial, carries with it the risks inherent to distancing people from the production chains, and no one cares how food and/or objects were produced anymore. As Gomes (2006) asserts, now emerges "the need for changes in the way of thinking, taking into account the current characteristics of modern society and favoring a comprehensive view of the world, with an ethical, responsible and supportive attitude ".

The transformation of modern society from a consumer society into a responsible consumer society is a pressing need, both from an ethical and a sustainable point of view, since, as Bauman $(2011,59)$ asserts, "An incidental victim of the leap to the consumerist version of freedom is the Other as an object of ethical responsibility and moral concern. "

The consumer paradigm shift is therefore urgent, which must be performed by all consumers as a positive response to those neglected by the market's voracity. The consumers' indifference when making their choices contributes in some way to human and/or environmental degradation. The Kant's voice ${ }^{2}$ on everybody's responsibility for the non-degradation of mankind, should not be made silent, on the contrary, should be echoed across all five continents, as a representative choir of fraternity.

\footnotetext{
${ }^{2}$ The duty of respect for my neighbor is contained in the motto not degrade any other human being, reducing it to a mere means to my ends (to not demand that others disregard themselves in order to enslave themselves in favor of my end." (KANT, 2003, p. 293).
} 


\section{ENVIRONMENTAL SUSTAINABILITY}

The current consumption society, a fruit of the Industrial Revolution, has generated increasing depredation of the natural resources. It is of common knowledge that they are finite and their extirpation entails very serious damage both for present generations and for future generations. In addition, the ecologically balanced environment is a fundamental right, provided by the Constitution (article 225 of CF/88) and its violation affects people's quality of life, resulting in a violation of the human dignity.

On this hand, it is important to highlight that globalization has contributed to the aggravation of the environment issue. Nowadays, life takes place in a world where multinationals use raw materials from one continent, and have their production in different one, sometimes weakening labor rights, sometimes excluding such rights completely. In this back and forth of the production chain, ships cross the oceans, promoting maritime pollution, all with the ultimate goal of reaching the consumer markets of greater purchasing power, that is, the developed countries. (PRADO, 2010).

On top of that, there is the discarding of the materials consumed in an irresponsible way, by consumers that are eager and compulsive for the novelties of the market, constituted, in most part, by electronics. Electronics are replaced, at breakneck speed, by younger generation. After that, they return to the environment as garbage. We witness the harmful actions to the environment and to human dignity, consisting on the discard of electronics consumed in First World countries (coming from North America and Europe) and dumped on the East Coast of the African Continent and in Asia (BBC BRAZIL, 2016).

Such disposal is through ships overflowing with electronics that cross the Atlantic Ocean and dump the objects in the African and Asian Continent. There, a crowds awaits the dump in hope of taking advantage of some parts by selling them in the market. In this fight for survival they are in serious danger of damaging their physical integrity, since the garbage is manipulated without any protection (BBC BRAZIL, 2016).

In addition, the heap of used and discarded electronics on the seashore also poses serious risks of damage to the environment, since people only manage to take advantage of a small part of the materials dumped on the continent, the other (larger) part remains there, without any use; pure electronic garbage out in the open ( electronic cemeteries ).In addition, waste pickers, in the handling of equipment, end up burning some materials, which generate the production of toxic substances in the atmosphere (BBC BRAZIL, 2016).

All this results from unbridled and irresponsible consumerism, and from a total negligence of the multinationals toward others on the opposite side of the ocean. This irresponsibility affects the lifes of those most vulnerable people, those who are unable to provide for their own subsistence in a dignified manner, and attempt to do so in the garbage dumps of the consumers from the modern liquid society (BAUMAN, 2001).

It can be seen, therefore, that the question of environmental sustainability is a universal human responsibility, not just local, especially in the modern world, marked by globalization, in which the actions related to the multinationals' chain of production spread across the five continents. What have we done to fight this environmental depredation?

At the international level, the environmental concern dates back to the beginning of the 20th century, when the first agreements with the aim of regulating human action on the environment were established between countries. Subsequently, the Antarctic Treaty was created (1959), ensuring the preservation of a natural environment as a result of an international meeting. (RIBEIRO, 2001). 
The United Nations (UN), through UNESCO (United Nations Educational, Scientific and Cultural Organization), began to make efforts for environmental preservation, and in 1949, there was the first major UNESCO action related to the environmental issue, the so-called United Nations Conference on the Conservation and Use of Resources (UNSCCUR), in the United States. This was followed, in 1968, by the Stockholm Conference on air pollution. And, in 1972, the participation of new agents in the defense of the environment begins, the Non-Governmental Organizations (NGOs). (RIBEIRO, 2001).

In 1972, the UN created UNEP (United Nations Environment Program), which began to gain strength in the development of the approach to environmental issues and culminated with Rio92, which resulted in a document (UNCED) containing various intentions of changes in the relationship between man and the environment, among them the need to strengthen sustainable development. (RIBEIRO, 2001).

Recently, the United Nations Conference on Sustainable Development, Rio + 20 (2012), marked the twenty years of the United Nations Conference on Environment and Development (Rio92) and help setting an agenda for sustainable development for the coming decades. (RIO20).

Domestically, little by little, society is becoming aware of the need for behavioral changes regarding responsible consumption. These changes began with the enactment of the 1988 Constitution, whereby an ecologically balanced environment was raised to the level of $a$ fundamental right.

Due to the seriousness of this situation of depredation of the environment, all these international instruments (and many others not covered herein) were created to avoid what is the worst of the nightmares: the destruction of the Planet itself.

\section{THE IMPACTS OF ETHICAL CONSUMPTION IN THE ECONOMY}

On an economic view, we could say that, in theory, the consumer makes his choices based on the price and desired qualities of a particular product. However, price does not encompass everything and these choices are not made in an informed manner. In this respect, Wessels teaches that (2000: 493):

\footnotetext{
"Without fraud, misinformation, and externalities, people left alone, will select the best goods to consume and produce them in the most efficient manner. This follows from the fact that free trade allows people to reallocate goods and inputs to their most valued use". ${ }^{3}$ (emphasis added).
}

That is fraud; misinformation and externalities imply that the economic system does not promote an efficient allocation of resources. But how can law and ethical consumption help to improve the efficiency of the economy?

In addition to the aforementioned cases of lack of ethics in consumption, numerous other examples of unethical corporate behaviors by companies can be mentioned, with fraud (bad faith) being one of them. Fraud makes certain companies gain competitive advantage by circumventing the laws. This is the case of tax evasion, non-compliance with environmental and labour laws, fraudulent bids, among others.

\footnotetext{
${ }^{3}$ Without fraud, misinformation and externalities, people, by themselves, will select the best products to consume and will produce them in the most efficient way. This stems from the fact that free trade allows people to reallocate products and inputs for their most valuable use.
} 
There is also the problem of diversion of illegally obtained resources (arms trafficking, money laundering from corruption and drug trafficking, clandestine casinos, etc.), which when directed to legally constituted companies can generate competitive advantages.

It is important to mention the inappropriate (and illegal) behavior of companies that conceal relevant information about product characteristics. Misinformation means that consumers do not have adequate knowledge of all information that could influence their consumption (MATACÁS, 2014, p. 262-263). The most classic case is that of misleading advertising, which in addition to violating art. 37 of the Code of Consumer Protection, violates the principle of good faith, which should govern legal relations in general.

Nowadays, with the society's growing concern with the environmental issue and with the respect for the dignity of the human person, information about the company's social and environmental behaviors can influence, increasing or decreasing, the desire of consumption of their products by individuals. It is the case of well-known brands of clothing and footwear that outsource services to countries that do not give dignified treatment to their workers or the case of multinational producers of chocolate that use cocoa obtained in farms that make use of child slave labour. Thus, if consumers were aware of such facts, they could demand ethical behavior on the part of the companies. After all, the gains obtained through the reduction of the costs of production would end up being undermined by the rejection of the product in the consumer market.

It is appropriate to draw some information about externalities. According to Rosen (1995, p.91) externalities occur "When the activity of one entity (a person or a firm) directly affects the welfare of another in a way that it is not transmitted by market prices" ${ }^{4}$. Taking this concept into account, it can be said that pollution, as a rule, is a negative externality. That is, it brings a social cost that is not encompassed by the price system. If the price system encompassed this information, the price of the products causing pollution would increase and its consumption would be discouraged. In addition, better information on the part of society can also make polluting practices and products less desirable to the consumer.

How can law and ethics contribute to addressing these issues?

Law can contribute by creating legislation that makes it more difficult to commit fraud and the fight against crimes more effective. Law can be used to give greater transparency to institutions and businesses, compelling government and companies to generate and make available more information. It can also create environmental protection policies and instruments and enforcement and punitive mechanisms. Since the 1988 Constitution, much progress has been made in Brazil in all fields, in consumer law, environmental law, and in the fight against crime and corruption. However, there is still much to do.

Notwithstanding, even if the legal system becomes more comprehensive and effective, consumer ethics has a large role to play. It is necessary for the consumer citizen to do his part and to, once aware that a company is involved in corruption, organized crime, disregard for fundamental rights, slavery, repeated disrespect to labor rights, environmental crimes, practices harmful to the development of a free, just and supportive society, take some action. First of all, stop consuming the services and products offered by the company, and the second step is to socially engage in the fight against such attitudes.

For example, if the consumer believes that a construction company is involved in corruption and organized crime, it is an ethical imperative that it does not consume the products of this company. The same treatment deserves to be applied to communication companies that do not act

\footnotetext{
${ }^{4}$ When the activity of one entity (person or company) directly affects the welfare of another one in such a way that this effect is not transmitted through market prices.
} 
in an impartial manner and that defend the interest of political and economic groups in detriment of the citizens. And even to those who disregard environmental laws, who use slave labour, who do not respect the dignity of the worker, who promote discrimination against women, and so on. In other words, there is a need for better training and awareness among citizens in regard to their power as consumers, for in the capitalist system it is perhaps the most effective way for citizens to be heard and have their rights respected.

\title{
6 SOCIAL RESPONSIBILITY
}

With the new Constitutional paradigm, supported by the defense of human rights and, as a reflex, by the promotion of the human dignity, it becomes noticeable that the whole society is responsible for promoting the human dignity, and not even the consumer can hide away from this duty. In what way, then, can we, consumers, contribute to forge an ethical conscience in our society?

Each social entity plays an important role within our society. The Government, by adopting public policies to encourage companies to produce ethical products, can actively participate in this endeavor. In what way? An example of proactive behavior by governments would be to make available to the general public the list of companies that do not meet the minimum required standards of human dignity in hiring their employees, throughout the production chain. Only then, can the consumer make the ethical choice of the products to be consumed. It so happens that, in the modernity, there are several multinationals that have their chain of production girded in several continents and, without the government transparency it is difficult for the consumer to ascertain whether the company is or is not ethical. By way of illustration, it is worth remembering the example of the chocolate industry:

\begin{abstract}
This is the case of large companies that produce chocolate, which although they are based in the developed countries, they hire companies established in countries such as Côte d'Ivoire to obtain cocoa and, in turn, use slave labor for the harvest of cocoa. The children, as reported in a documentary screened by the Danish TV called "The Dark Side of Chocolate" in March 2010, are explored in the cocoa plantations, located in Cote d'Ivoire (BERTONCINI; LINS, 2016, p. 208).
\end{abstract}

And this is just one example, among so many others, of profiteering from either the worker or the environment.

On the other hand, the Government can also intervene through sanctions or incentives (reward sanctions) for the promotion of ethical consumption, which stimulate the consumer to make the right choices. These measures aim at the general interest (environment) or a particular group of people, as in the case of the exploitation of workers. The Government may impose penalties and/or incentives on both businesses and consumers. In this sense, the State of Rio de Janeiro contributes to ecological balance by making companies offer discounts to consumers who do not use plastic bags (Act No. 5.502/2009) $)^{5}$. (ZANITELLI, 2010, p. 28).

\footnotetext{
${ }^{5}$ Art. 3 - After expiration of the term established in $\$ 3$ of art. 2 of this Law, the establishments referred to in the heading of the same article that have not yet promoted the substitution referred to in this Law are obliged to receive plastic bags and bags to be delivered by the general public, regardless of their state of conservation and origin, with one of the following considerations: I - every 5 (five) items purchased at the establishment, the customer who does not use a plastic bag will be entitled to a discount of at least $\mathrm{R} \$ 0.03$ (three BRL cents) on their purchases; II - the exchange of $1 \mathrm{~kg}$ (one kilogram) of rice or beans for every 50 (fifty) plastic bags delivered by any person.
} 
Another way of promoting the human dignity through ethical consumption is the example given by the State of Paraná, through the well-known "Taxpayer ID on Invoice" ("CPF na nota") (PARANÁ).The consumer, when making his purchase, requests the inclusion of his Individual Taxpayer's ID (CPF) in the Invoice, therefore ensuring the payment of the tax due to the Government. Through the greater collection by Government, the society, in theory, is the first to be benefited, with the improvement of the public policies provided by the state (education, health, security and others).

It is important to highlight the importance of education in the behavioral change of society in relation to consumption. The role of schools in shaping of a new mindset based on fraternity and the preservation of the environment is decisive in achieving the objective of ethical and sustainable consumption ${ }^{6}$.

Companies, in its turn, also play an important role in promoting the human dignity, to the extent that they make ethically manufactured products available on the market, aiming at social welfare and environmental protection. It should be noted that the 1988 Constitution emphasizes in art. 170, caput, that the economic order is based on the value of human labour and is intended to ensure everyone a life with dignity, observing the principle of social role of property, provided in subsection III.

Corporate responsibility, as set out in the Constitution, is reflected in consumer relations, in a way that calls on private enterprise to act in accordance with the dictates of social justice. Therefore, companies are expected to treat their employees in a fair manner, to avoid selling products that are harmful to the environment and to collaborate in solving social issues, in that way contributing to a reduction in the number of human rights violations.

With regard to consumers, it should be emphasized that their social role in promoting human dignity and ecological balance is quite important, perhaps essential, within the globalized world. The choices we make in the market have universal implications. Our consumption habits are responsible for the maintenance or not of an ethical or unethical company, since, as Von Mises (2013, p. 29) asserts, the consumer is sovereign in the market, and it is he who will determine which companies should remain sound in the market and which ones will perish by the influence of free competition.

This power of paradigm change that we consumers have in making our choices of consumption reminds us of the relevant social role we have in promoting human dignity. In large and small acts of consumption, large social responsibilities arise. Should I consume a product from the exploitation of human labour? That uses slave labour? That has been produced in a way to degrade the environment or contribute to the extinction of species? Should I only change products to keep up with fashion in this discarding society? Or is my social responsibility greater than all these?

Highlights the teachings of Herrera Flores (2009, p. 169), on the liberation of man from unbridled consumption:

Hence the need to repossess time and now, freeing life from the dominance of the competitive view and freeing from the desire for the product to be consumed. We must put desire in its proper place: the desire for a better world, a possible and counterhegemonic world, that allows us to escape from the prison in which these new processes of social and human control have chained us.

\footnotetext{
6 "Education must have new meanings in the construction of a sustainable, democratic, participatory and socially just society capable of effectively exercising solidarity towards the present and future generations. And if it is not synonymous to solution, education is undoubtedly the best way to improve our society. " (GOMES, 2006, p. 25).
} 
The realization of this "better world", advocated by Herrera Flores, depends on the undertaking of responsibilities by all social agents. For the consumer to be able to make the ethical choices of products, it depends, sometimes, on the transparency of government or of the companies themselves about the way they produce their products. On the other hand, in order to change consumer habits, it is important that the Government and the private sector promote education for ethical consumption both in schools and in the media in general. Indeed,

it is verified that the functionalization of the company ends up determining a movement of citizenship consumption, of conscious consumption. The consumer, within this new perspective, can no longer be seen as a simple means of satisfying profit-making business interests. He must be seen as the citizen he is, with the guarantees that are granted to him and with the needs that are inherent to him. New needs should not be presented to him at every minute with the sole aim of stimulating unbridled consumption. In short, consumers must be given the real possibility of choosing to consume or not to consume, thus encouraging an effort to reflect on their real needs. Having made the conscious choice for consumption, it should be made possible for the consumer, by means of broad and precise information, to choose the product or service according to their reflexes not only in their personal sphere, but also taking into account social, economic and environmental reflexes (BERTONCINI; OIKAWA, 2013, p.314).

It is important to emphasize that in life our choices have universal implications and that good habits, based on ethics for the future, is capable of changing the world for better, preserving human dignity and sustainability.

\section{CONCLUSION}

The research verified the existence of an ethical problem based on the society's unbridled consumption of new products, which are increasingly frequent in the disposable market. In modern times, there is a prevalence of a liquid society, whose greatest interests are personal satisfaction and the frantic search for the happiness of the new object to be possessed.

It was determined the need to rescue human dignity through responsible consumption, conscious choices to discourage companies from unfair market practices.

The consequences on the environment of such excessive consumption were also verified, with repercussions in all the continents. Some commercial actions harmful to the ecosystem were analyzed. From the analysis of some international instruments to protect the environment, it was noticed an increasing environmental concern since the beginning of the 20th century, culminating in Rio + 20 in Brazil in 2012.

Issues related to economics and ethical consumption were raised. There is the need for market to seize the negative externalities, as a means of discouraging the practices of entrepreneurs. It was observed the need to create laws to prevent the occurrence of fraud, as well as the need for accountability for good consumer practices of all social entities.

It is concluded, therefore, that, in matters of consumer ethics, a broad social engagement is required of all social entities, in the sense of avoiding any type of anti-ethical or unethical consumption behavior. From the manufacturing of the product to its marketing, good habits, good faith in business, the correct choices by consumers and government oversight and transparency are, in short, the determining factors in the promotion of human dignity and a sound environment.

Finally, it is important to emphasize that ethical consumption does not necessarily preclude economic growth; on the contrary, as a factor to be applied to all economic agents, it will 
probably exclude from the market those who are disloyal in their business and consumer practices, since conscious consumption will naturally preserve loyal and socially responsible businesses.

\section{REFERENCES}

BAUMAN, Zygmunt. A ética é possível num mundo de consumidores? Rio de Janeiro: Zahar, 2011.

BAUMAN, Zygmunt. Vida para consumo: A transformação das sociedades em mercadoria. Rio de Janeiro: Zahar, 2008.

BAUMAN, Zygmunt. Vidas Desperdiçadas. Rio de Janeiro: Zahar, 2005.

BAUMAN, Zygmunt. Modernidade Líquida . Rio de Janeiro: Zahar, 2001.

BBCBRASIL. O país da África que se tornou um cemitério de eletrônicos. Disponível em: <goo.gl/FduIVjcontent_copyCopy short URL>. Acesso em: 08 dez. 2017.

BERTONCINI, Mateus; LINS, Elaine Braga Martins Ribeiro. Instrumentos jurídicos e ações sociais no combate ao trabalho escravo infantil. In: VERONESE, OLIVEIRA, MOTA (Org.). O direito no século XXI: o que a fraternidade tem a dizer. Florianópolis: Insular, 2016, p. 199-218.

BERTONCINI, Mateus; OIKAWA, Mariana Mendes Cardoso. O consumo consciente e a educação para o consumo como função social da empresa. Revista Jurídica, v. 4, n. 33, 2013, p. 298-319. Disponível em: 〈goo.gl/MBHYfp>. Acesso em: 08 dez. 2017.

BRASIL. Constituição Federal de 1988. Disponível em: 〈goo.gl/wUgZP〉. Acesso em: 08 dez. 2017.

FERRAJOLI, Luigi. Por uma teoria dos direitos e dos bens fundamentais. Porto Alegre: Livraria do advogado Editora, 2011.

GOMES, Daniella Vasconcellos. Educação para o consumo ético e sustentável. UFRGS, v. 16, jan junho 2006. Disponível em: 〈goo.gl/VV2LCL〉. Acesso em 08 dez. 2017.

HERRERA FLORES, Joaquim. A (re)invenção dos direitos humanos. Florianópolis: Fundação Boiteux, 2009.

JONAS, Hanz. O princípio responsabilidade: ensaio de uma ética para a civilização tecnológica. Rio de Janeiro: Contraponto/PUC-Rio, 2006.

KANT, Immanuel. A metafísica dos costumes. São Paulo: EDIPRO, 2003.

MARKETANALYSIS. Dispõe sobre a substituição e recolhimento de sacolas plásticas em estabelecimentos comerciais. Disponível em: 〈goo.gl/t9MTHT〉. Acesso em: 08 dez. 2017. 
MATACÁS, María Rosa Llácer. Instrumentos jurídicos para la autodeterminación personal: relaciones de consumo, comunicaciones comerciales, privacidad y smart society. Revista de Direito Brasileiro, ano 4, vol. 9, Edição Especial, 2014, p. 258-285. Disponível em: <goo.gl/FkpAqC>. Acesso em: 08 dez. 2017.

PARANÁ. Secretaria da fazenda. CPF na nota é dinheiro de volta. Disponível em: <goo.gl/m75OTz>. Acesso em: 08 dez. 2017.

PIOVESAN, Flávia. Direitos humanos e o direito constitucional internacional. São Paulo: Saraiva, 2009.

PRADO, Hayrton Rodrigues do. A poluição causada pelos navios. Disponível em: <goo.gl/UeHKYA>. Acesso em: 08 dez. 2017.

RIO DE JANEIRO. Dispõe sobre a substituição e recolhimento de sacolas plásticas em estabelecimentos comerciais. Disponível em: <https://goo.gl/7KxRme>. Acesso em: 8 dez. 2017.

RIO 20. Sobre a Rio+20. Disponível em:〈goo.gl/Y6VWrf〉. Acesso em: 08 set. 2017.

ROSEN, Harvey S. Public Finance. Chicago: Irwin, 1994.

SÁNCHEZ VÁSQUEZ, Adolfo. Ética. Rio de Janeiro: Civilização Brasileira, 2013.

SARLET, Ingo Wolfgang. A eficácia dos direitos fundamentais: uma teoria geral dos direitos fundamentais na perspectiva constituicional. Porto Alegre: Livraria do advogado editora, 2011.

STJ BDJUR. A boa fé na relação de consumo. Disponível em: <goo.gl/J9mVbg> Acesso em: 08 dez. 2017.

VON MISES, Ludwig. A mentalidade anticapitalista. Rio de Janeiro: Instituto Liberal, 2013.

WESSELS, Walter J. Economics. New York: Barron's, 2000.

YOUTUBE. O lado negro do chocolate. Documentário. 2010. Disponível em: 〈goo.gl/XS1yjw〉. Acesso em: 08 dez. 2017.

ZANITELLI, Leandro Martins. Direito e consumo ético: uma comparação entre a análise econômica das normas sociais e a teoria do comportamento planejado. PUC RJ, outubro 2010. Disponível em: 〈goo.gl/C12RjH>. Acesso em: 08 dez. 2017. 